\title{
Dialysate Flow: Is the Less the Better?
}

\author{
Alejandra Molano-Triviño ${ }^{\mathrm{a}}$ Gustavo Guzmán ${ }^{\mathrm{b}}$ Ángel Galván ${ }^{\mathrm{c}}$ \\ Daniel Ducuara $^{d}$ Anthony Martínez ${ }^{e}$ Alberto Yúnez ${ }^{f}$ \\ ${ }^{a}$ Department of Nephrology, RTS, Fundación Cardioinfantil, Nephrology Postgraduate Director, Universidad \\ del Rosario, Bogotá, Colombia; 'b Department of Nephrology, Fundación Santa Fe de Bogotá, Bogotá, Colombia; \\ 'Department of Nephrology, Universidad del Rosario, Bogotá, Colombia; ${ }^{d}$ Department of Nephrology, RTS

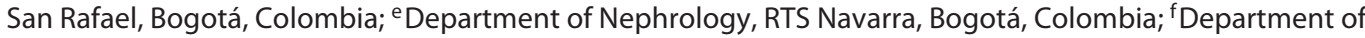 \\ Nephrology, RTS, Medellín, Colombia
}

Dear Editor,

Greetings from Colombia!

It was a pleasure to read your article "Differential Molecular Modeling Predictions of Mid and Conventional Dialysate Flows (Qd)".

Minimization of Qd is a matter of interest for our group not only in terms of dialysis efficiency and patient safety but also in terms of reduction of wastage in water.

Since 2012, we have been prescribing Qd $400 \mathrm{~mL} / \mathrm{min}$ for small patients, and we have already shared our experience $[1,2]$.

We have performed 2 in vivo comparative trials between Qd 400 and $500 \mathrm{~mL} / \mathrm{min}$ with polynephron membranes with a thrice-a-week, 4-h hemodialysis (HD) scheme for patients with weight $<70 \mathrm{Kg}$ in a cross trial prescription of Qd 400 and $500 \mathrm{~mL} /$ $\min [3]$.

We found no differences in Kt/V, phosphate, hemoglobin, potassium, and interdialytic gain between our Qd groups Table 1 [3].

Recently we have successfully finished our 5-year analysis of mortality between Qd 400 and $500 \mathrm{~mL} / \mathrm{min}$ in a chronic HD population in Colombia. Our results were shared in the ISN Congress next April in Melbourne in the poster session on the topic green nephrology as one of our Blue Planet dialysis initiatives [2].

We have seen in our previous results, as you did now in your interesting article, that a reduced Qd means no differences in dialysis efficiency, but we dare to add another interesting conclusion: we have estimated savings of potable water: with Qd reduction: $24 \mathrm{~L}$ of potable water was saved in each 4-h HD session per patient with a slight reduction of Qd (120 L/session in Qd $500 \mathrm{~mL} /$ min vs. $96 \mathrm{~L} / \mathrm{session}$ in Qd $400 \mathrm{~mL} / \mathrm{min}$ ).

\section{KARGER}

(C) 2019 S. Karger AG, Basel

E-Mail karger@karger.com

www.karger.com/bpu
Table 1. Comparison between Qd 400 and $500 \mathrm{~mL} / \mathrm{min}$ [9]

\begin{tabular}{lccc}
\hline & Qd & Qd & \multirow{2}{*}{$p$ value } \\
& $400 \mathrm{~mL} / \mathrm{min}$ & $500 \mathrm{~mL} / \mathrm{min}$ & \\
\hline Interdialytic weight gain & $2.37 \pm 0.7$ & $2.41 \pm 0.6$ & 0.41 \\
Kt/V & $1.57 \pm 0.25$ & $1.59 \pm 0.23$ & 0.45 \\
Serum phosphorus, mg/dL & $4.5 \pm 1.2$ & $4.4 \pm 1.2$ & 0.56 \\
Hemoglobin, g/dL & $11.3 \pm 1.8$ & $11.3 \pm 1.6$ & 0.96 \\
Serum potassium, mg/dL & $4.9 \pm 1.1$ & $5.1 \pm 1.0$ & 0.45 \\
\hline
\end{tabular}

Qd, dialysate flow.

When extrapolating our results to 100 patients, our reduction of Qd would result in an annual saving of 345,600 L of water, which is remarkable compared to World Health Organization minimum for basic health protection of at least $20 \mathrm{~L}$ per person/day: our saving equals the minimal amount of water for 1 adult for 47 years [2-4].

We hope that your efforts and interesting results will motivate nephrologists around the world to reduce Qd and reduce the ecological impact of renal replacement therapies to present $\mathrm{HD}$ as an affordable therapy in places with water scarcity.

\section{Disclosure Statement}

The authors have no conflicts of interest to disclose.

Alejandra Molano-Triviño

RTS - Fundación Cardioinfantil - Universidad del Rosario

110121 Bogotá

Colombia

E-Mail alepatrimoltri@gmail.com 


\section{References}

1 Martinez A, Ducuara D, Molano A. Efecto de ajuste del flujo dializante (Qd) sobre la eficacia en hemodiálisis a pacientes de bajo peso. Rev Cienc Salud. 2013;11(2):17584.

2 Molano-Triviño A, Wancjer B, Neri MM, Karopadi AN, Rosner M, Ronco C. Blue Planet dialysis: novel water-sparing strategies for reducing dialysate flow. Int J Artif Organs. 2017, Epub ahead of print.

3 Molano-Triviño A, Wancjer Meid B, Guzman G, Yunez Luqueta A, Beltrán J, Romero G, Ronco C. Effects of decreasing dialysis fluid flow rate on dialysis efficacy and interdialytic weight gain in chronic patients with hemodialysis - FLUGAIN Study. Nephrology
Dialysis Transplantation. 2018;33(suppl_1): i514-5.

4 Molano-Triviño A, Ronco C, Galván A, G, Wancjer B, Sanabria RM, Vesga J. Long term outcomes of lowering dialysate flow (QD) in a population of Chronic hemodialysis in rts. Colombia: Abstract number WCN 19-0387, ISN Congress Melbourne, 2019. 